\section{Vegetation-free Area Influences Growth and Establishment of Rabbiteye Blueberry}

\author{
D. Scott NeSmith \\ Department of Horticulture, Georgia Station, Griffin, GA 30223-1797
}

Gerard Krewer

Department of Horticulture, The University of Georgia, P.O. Box 1209, Tifton, GA 31793

Additional index words. Vaccinium ashei, weed control

\begin{abstract}
Tifblue' and 'Brightwell' rabbiteye blueberries (Vaccinium ashei Reade) were planted in 1992 in a tall fescue (Festuca arundinacea Schreb.) sod. Vegetation-free areas of various sizes were maintained around plants to determine the area's influence on establishment and growth of young plants. Vegetation-free circles 0 (control), 0.6, 0.9, and $1.5 \mathrm{~m}$ in diameter were maintained from 1992 to 1994 by a combination of commercially recommended herbicides and hand-weeding. The treatments resulted in vegetation-free areas of $0,0.3,0.6$, and $1.8 \mathrm{~m}^{2}$. Fall growth index values (derived from canopy height and width measurements) increased with size of vegetation-free area in each of the three years. The response was positive linear and negative quadratic, with little difference between the 0.6- and 1.8- $\mathrm{m}^{2}$ vegetation-free areas. Average shoot length in Fall 1992 showed a response similar to that of the growth index; total shoot count per plant was not affected by the treatments. Percent fruit set was not influenced by treatments; however, the number of flower buds per plant in Spring 1994 was correlated positively with size of vegetation-free area. The cultivars responded similarly. Thus, vegetation control seems to be important in establishing young rabbiteye blueberry plants, with the optimum vegetation-free area between 0.6 and $1.8 \mathrm{~m}^{2}$ during the first 2 to 3 years after planting.
\end{abstract}

The continued expansion of the rabbiteye blueberry industry in the southeastern United States is coupled with many uncertain issues of orchard establishment. A major concern of growers is the control of undesirable vegetation, particularly during the first few years after planting. There is considerable information available on vegetation management for tree fruit crops (Hogue and Neilsen, 1987); however, there have been few reports of vegetation management for the establishment of blueberries. Yarborough and Ismail (1985) indicated that increased weed control with the herbicide 3-cyclohexyl-6-(dimethylamino)-1methyl-1,3,5-triazine-2,4(1H,3H)-dione (hexazinone) increased flower bud count and yield of lowbush blueberry (Vaccinium angustifolium Aiton). Patten et al. (1989) showed no effect of sodded alleys vs. tilled alleys on canopy growth and crop yield of rabbiteye blueberry; they maintained a $1.2-\mathrm{m}$ vegetation-free band around plants with herbicide applications. These findings suggest that some degree of vegetation-free area is benefi-

Received for publication 31 Mar. 1995. Accepted for publication 10 July 1995 . A contribution of the Univ. of Georgia Agricultural Expt. Station, Georgia Station, Griffin. This research was supported by a grant from Michigan Blueberry Grower's Marketing and by state and Hatch Act funds allocated to the Georgia Agricultural Expt. stations. The cost of publishing this paper was defrayed in part by the payment of page charges. Under postal regulations, this paper therefore must be hereby marked advertisement solely to indicate this fact. cial in establishing blueberries; yet, the extent of the area needed remains unclear.

In general, vegetation surrounding newly planted orchard crops may reduce growth and crop plant vigor by allelopathy or competition for water and nutrients (Hogue and Nielsen, and 1994 , respectively.
1987). Undesirable vegetation can be removed via cultivation; however, tillage may damage crop root systems when conducted too close to the plant (Hogue and Nielsen, 1987; Welker and Brogdon, 1968). Because of these factors, herbicides are used widely to manage vegetation in most orchard crops.

Information concerning threshold vegetation-free areas for optimum crop establishment would benefit blueberry growers by decreasing the crop establishment period and by reducing herbicide and labor costs associated with excess vegetation management. Our objective was to examine early growth of two rabbiteye blueberry cultivars in response to varying vegetation-free areas in a fescue sod.

\section{Materials and Methods}

In Winter 1992, we obtained 2-year-old 'Tifblue' and 'Brightwell' rabbiteye blueberry plants from a commercial nursery. These plants were set at the Georgia Expt. Station, Griffin, into an existing fescue sod in Mar. 1992 in a Cecil sandy clay loam (clayey, kaolinitic, thermic Typic Hapludult) with a pH of 5.0 to 5.2. Plant spacing was $3.7 \mathrm{~m}$ between rows and 1.8 $\mathrm{m}$ between plants in a row. A split-plot design was used, with cultivar being the main plots. Each row contained eight plants of the selected cultivar. The following subplots of vegetation-free circles of varying diameters were established using herbicides (in meters): 1) no herbicide (only mowing every 4 to 6 weeks), 2) $0.6,3) 0.9$, and 4) 1.5 . These treatments resulted in vegetation-free areas of $0,0.3,0.6$, and $1.8 \mathrm{~m}^{2}$. Ten plants of each cultivar received each treatment. We used 1,1'-dimethyl4-4'-bibyridinium ion (paraquat) and 4(dipropylamino)-3,5-dinitrobenzene-

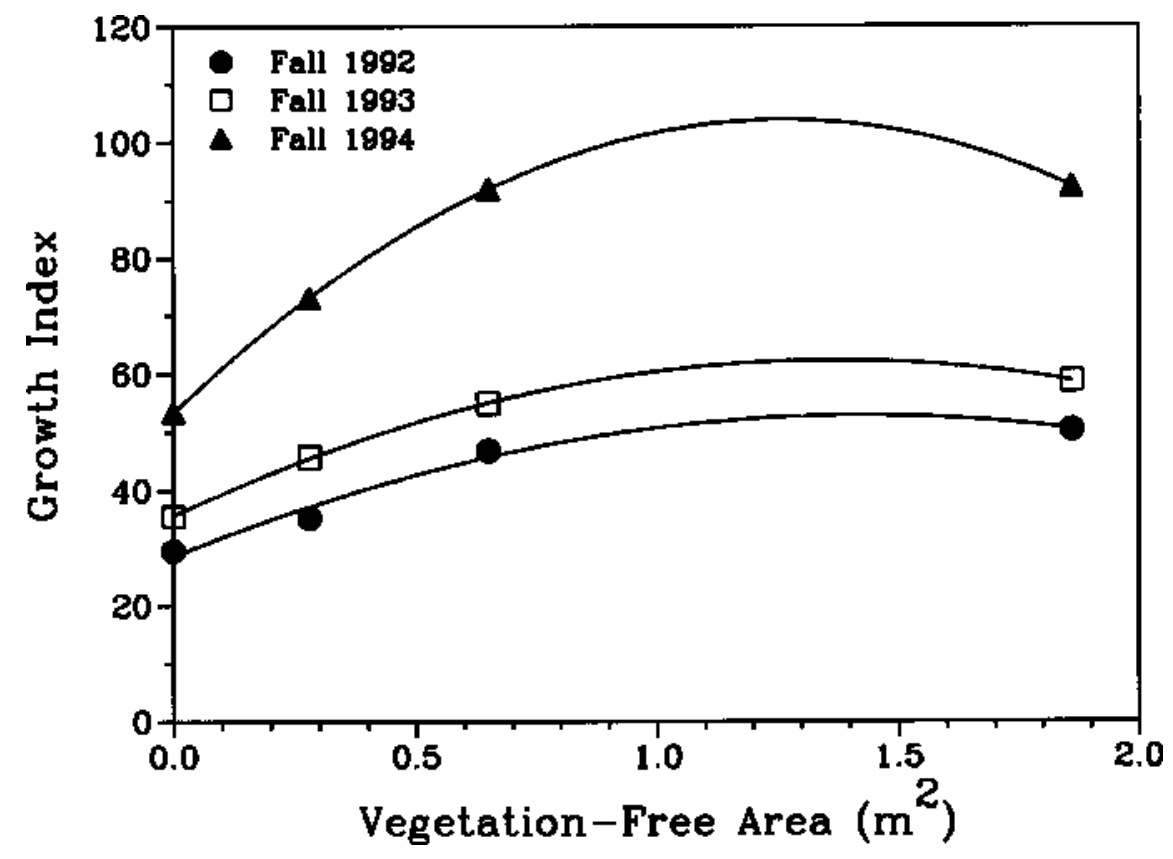

Fig. 1. Growth index (derived from canopy height and width measurements) in Fall 1992, 1993, and 1994 for rabbiteye blueberry in response to vegetation-free area. Regression equations were $y=29+34 x-$ $12 \mathrm{x}^{2}\left(R^{2}=0.98\right), \mathrm{y}=36+39 \mathrm{x}-14 \mathrm{x}^{2}\left(R^{2}=0.99\right), \mathrm{y}=53+80 \mathrm{x}-32 \mathrm{x}^{2}\left(R^{2}=0.99\right)$ for Fall 1992, 1993, 
sulfonamide (oryzalin) at 0.8 and $3.4 \mathrm{~kg}$ a.i./ ha, the rates recommended by Brown (1993). These herbicides were applied 1 month after planting and were used periodically during the experiment in conjunction with hand-weeding to maintain the vegetation-free areas. Sod outside of the treated areas was mowed every 4 to 6 weeks. Plants were grown primarily without irrigation, with the exception of three overhead irrigation events in extreme drought situations ( $<25 \mathrm{~mm}$ of rain over 4 weeks during active growth). Soil tests were made annually, and fertilizer was applied according to recommendations.

Plant growth was monitored during 1992 through 1994. Canopy height (h) and width (w) were measured (in centimeters) every 4 to 6 weeks during the growing season. These measurements were used to calculate a growth index $(\mathrm{GI})$ : $\mathrm{GI}=(\mathrm{h} \times \mathrm{w}) / 100$. The height and width measurements were taken as an average at the tallest and widest points of the canopy. In Fall 1992, following the first year's growth, total shoot length and count were determined for each plant. Flower buds were counted in Spring 1994 for each plant. Fruit counts subsequently were made for the entire plant in 1994. To obtain an estimate of total flower count, bud count was multiplied by 6 , which has been shown to be the average number of flowers per bud for these cultivars (Lyrene and Goldy, 1983; D.S.N., unpublished data). Fruit set was estimated from the fruit and flower counts. The data were subjected to regression analysis.

\section{Results and Discussion}

In general, there was no significant cultivar difference in response to treatments; hence, cultivar data were pooled for analyses. Although GI was measured several times during the growing season, only fall data are presented because they indicated the cumulative effect for a particular year. By the end of the first year (Fall 1992), there was a significant increase in the GI of both cultivars as vegetation-free area increased (Fig. 1). A similar effect was apparent in subsequent years. There was a positive linear and negative quadratic response of GI as vegetation-free area increased; however, there generally was little difference in GI between 0.6- and 1.8- $\mathrm{m}^{2}$ vegetation-free areas. Research with young peaches [Prunus persica (L). Batsch.] indicated that a vegetation-free area of 6 to $8 \mathrm{~m}^{2}$ gave maximum growth response (Welker and Glenn, 1985); this likely would not be the case with rabbiteye blueberry.

The first fall following plant establishment (1992), average shoot length increased with diameter of the vegetation-free area (Fig. 2). The response again was positive linear and negative quadratic, with little difference between the larger two areas. There was no influence of vegetation management on number of shoots per plant; both cultivars averaged around 40 shoots per plant.

Flower bud count per plant in Spring 1994 showed a strong positive correlation with vegetation-free area (Fig. 3). Increasing proximity of vegetation to the blueberry plants likely

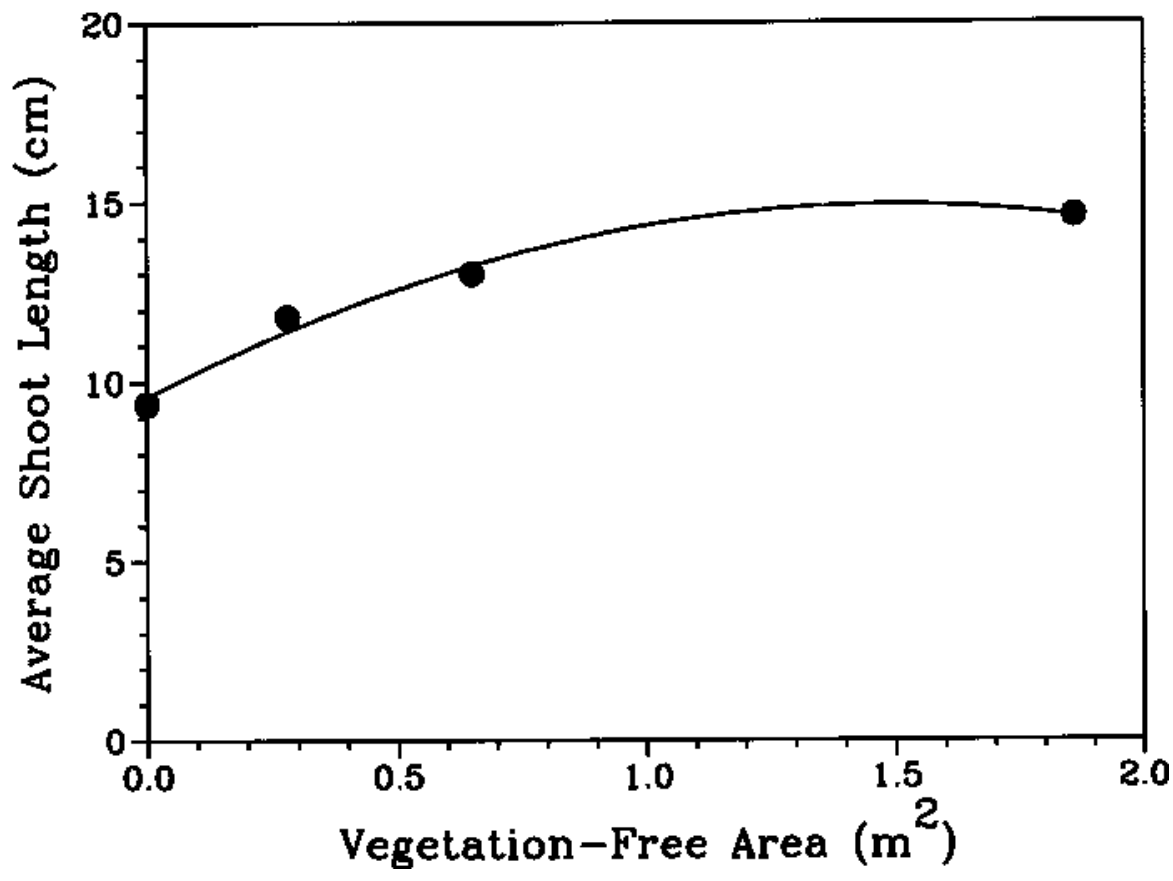

Fig. 2. Average shoot length in Fall 1992 for rabbiteye blueberry in response to vegetation-free area. Regression equation was $\mathrm{y}=9.6+7.1 \mathrm{x}-2.4 \mathrm{x}^{2}\left(R^{2}=0.98\right)$.

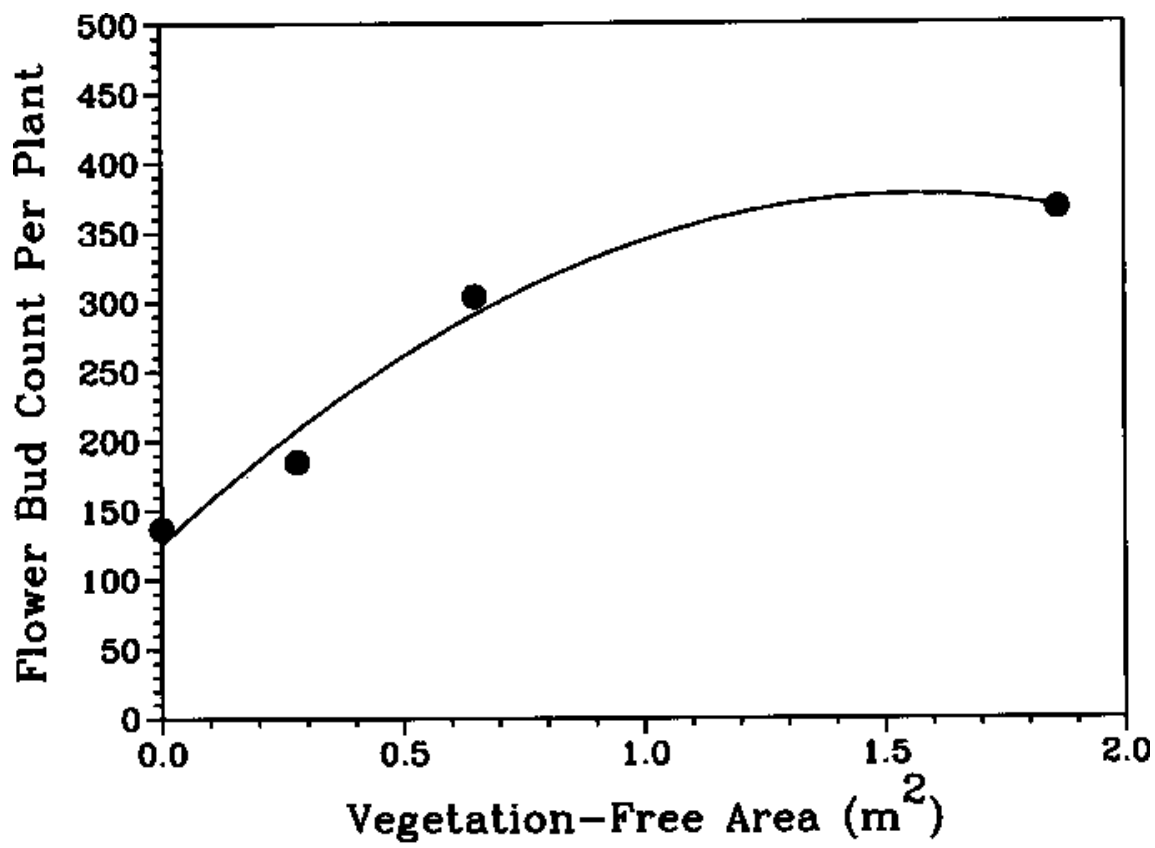

Fig. 3. Flower bud number per plant in Spring 1994 for rabbiteye blueberry in response to vegetation-free area. Regression equation was $\mathrm{y}=126+321 \mathrm{x}-102 \mathrm{x}^{2}\left(R^{2}=0.98\right)$.

increased competition for water and nutrients. Water and nutrient stress in blueberry reduces plant vigor, and reduced plant vigor often results in fewer flowers per shoot (Darnell et al., 1991). Fruit set was estimated in early Summer 1994, and no treatment effects were found (data not shown). 'Brightwell' averaged $\approx 30 \%$ fruit set, and 'Tifblue' averaged $<15 \%$. These low fruit set values are typical for open-pollinated rabbiteye blueberries (Lyrene and Crocker, 1983).

Overall, these data indicate that there is an increase in vegetative growth and yield potential of young rabbiteye blueberries in response to vegetation control. Increasing the vegetation-free area accelerated early growth of all treatments. However, it appears the optimum vegetation-free area for vigorous growth and flower bud development is between $0.6 \mathrm{~m}^{2}$ and $1.8 \mathrm{~m}^{2}$. A grower with $1.8 \mathrm{~m}$ between plants likely would get maximum growth response of young rabbiteye blueberries by maintaining a vegetation-free band around plants of $0.6 \mathrm{~m}$ to $0.9 \mathrm{~m}$. 


\section{Literature Cited}

Brown, S.M. 1993. Commercial weed control, p. 230-231. In: K.S. Delaplane (ed.). Georgia pest control handbook. Coop. Ext. Serv. Spec. Bul. 28. Univ. of Georgia, Athens.

Darnell, R.L., G.W. Stutte, G.C. Martin, G.A. Lang, and J.D. Early. 1991. Developmental physiology of rabbiteye blueberry. Hort. Rev. 13:339405.

Hogue, E.J. and G.H. Nielsen. 1987. Orchard floor vegetation management. Hort. Rev. 9:377-430.
Lyrene, P.M. and T.E. Crocker. 1983. Poor fruit set on rabbiteye blueberries after mild winters: Possible causes and remedies. Proc. Fla. State Hort. Soc. 96:195-197.

Lyrene, P.M. and R.G. Goldy. 1983. Cultivar variation in fruit set and number of flowers per cluster for rabbiteye blueberry. HortScience 18:228229.

Patten, K.D., E.W. Neundorff, G.H. Nimr, S.C. Peters, and D.L. Cawthon. 1989. Growth and yield of rabbiteye blueberry as affected by orchard floor management practices and irrigation geometry. J. Amer. Soc. Hort. Sci. 114:728732.

Welker, W.V. and J.L. Brogdon. 1968. Response of highbush blueberries to long-term use of diuron and simazine. Weeds 16:303-305.

Welker, W.V. and D.M. Glenn. 1985. The relationship of sod proximity to the growth and nutrient composition of newly planted peach trees. HortScience 20:417-418.

Yarborough, D.E. and A.A. Ismail. 1985. Hexazinone on weeds and on lowbush blueberry growth and yield. HortScience 20:406-407. 